\title{
The impacts of a Laki-like eruption on the present Swedish society
}

\author{
Karin Mossberg Sonnek ${ }^{1}$ - Tomas Mårtensson ${ }^{2} \cdot$ \\ Ester Veibäck ${ }^{1} \cdot$ Peter Tunved $^{3} \cdot$ Håkan Grahn ${ }^{4}$. \\ Pontus von Schoenberg ${ }^{4} \cdot$ Niklas Brännström $^{4}$. \\ Anders Bucht ${ }^{4,5}$
}

Received: 16 May 2016/ Accepted: 18 May 2017/Published online: 31 May 2017

(C) The Author(s) 2017. This article is an open access publication

\begin{abstract}
In this study, we analyse and discuss the possible impacts on the Swedish society of a volcanic eruption on Iceland, emitting ash particles and large quantities of sulphur dioxide. A scenario was developed, based on the historical Laki eruption of 1783-1784, to describe the content of a potential sulphur fog over time in Sweden. Due to its high complexity and the many uncertainties in the underpinning scientific data, the scenario was developed using a cross-disciplinary approach incorporating experts from different scientific fields. An analysis of the impacts of the hazard on human health, environment and technical equipment was then performed and, finally, representatives from national authorities assessed the overall societal challenges in responding to the consequences of a massive volcanic eruption. The analysis shows that it is the peak concentrations of sulphur dioxide and sulphuric acid rather than the longer periods of moderate concentrations that contribute most to the negative consequences for human health and environment. Altogether, three societal challenges were identified: the ability to compile and disseminate relevant information fast enough, to perform continuous measurements of concentrations of different substances in affected areas and to meet the large demand for medical care.
\end{abstract}

Keywords Laki-like eruption · National risk assessment - Sulphur fog · Scenario development · Dispersion modelling · Health impacts

Karin Mossberg Sonnek

karin.mossberg@foi.se

1 Division of Defence Analysis, Swedish Defence Research Agency, Stockholm, Sweden

2 Division of Defence and Security Systems, Swedish Defence Research Agency, Stockholm, Sweden

3 Department of Environmental Science and Analytical Chemistry, Stockholm University, Stockholm, Sweden

4 Division of CBRN Defence and Security, Swedish Defence Research Agency, Umeå, Sweden

5 Unit of Respiratory Medicine, Department of Public Health and Clinical Medicine, Umeå University, Umeå, Sweden 


\section{Introduction}

\subsection{Background}

During the summer of 1783, people in Europe and in parts of North America experienced a dry, dense fog with a sulphuric smell that reduced visibility. The fog caused eye irritation, headaches and difficulty in breathing, especially for asthmatics (Grattan and Pyatt 1999). Mortality increased in many countries, e.g. the death rate in England 1783-1784 was estimated to be $17 \%$ higher than the projected trend for the same period (Grattan et al. 2003). Also, a wide variety of plants were affected and consequently throughout Europe crops were partially destroyed (Thordarson 1995). Several eighteenth-century written sources bear witness to significant crop failures (Grattan and Durand 2003), which in combination with the unusually cold winter that followed (Thordarson and Self 2003) may have contributed to the many deaths during the period.

The sulphur fog was caused by a series of eruption episodes of the Laki volcano on Iceland during an 8-month period in 1783-1784 (Thordarsson and Self 1993; Thordarson et al. 1996). Besides the local volcanic haze that settled above Iceland at low altitudes, i.e. $<5 \mathrm{~km}$, fine ash particles, sulphur dioxide $\left(\mathrm{SO}_{2}\right)$ and other gases were dispersed in the upper troposphere and lower stratosphere (7-14 km). As suggested by Thordarson and Self (2003), the sulphur-rich plume was transported eastward to Europe by the polar jet stream and reintroduced to the surface by subsiding air masses in a high-pressure cell. The extreme volcanic pollution affected the northern hemisphere for more than 5 months. In addition to the impacts in Europe, the eruption had devastating impacts on Iceland's ecology and caused the death of around a quarter of its human population (Thordarson and Self 2003; Grattan and Durand 2003).

Volcanic eruptions on Iceland occur every 3-4 years (Gudmundsson et al. 2008), while the recurrence interval of a Laki-like eruption is much longer. Schmidt et al. (2012) estimate, based on historical data, that a Laki-like eruption occurs once in 200-500 years. Although Europe has experienced several volcanic eruptions, in modern times the Eyjafjallajökull 2010 has mainly affected air traffic. However, in September 2014, the northern parts of Norway and Sweden experienced sulphuric haze of low intensity derived from the Holuhraun eruption in 2014-2015, but with no reported societal impacts (Grahn et al. 2015).

If a Laki-like eruption were to happen today, it is uncertain how it would affect Sweden's environment and the health of its population. The Swedish Civil Contingencies Agency (MSB) therefore initiated an analysis of the consequences of a Laki-like eruption and the potential societal challenges for Sweden. The analysis was done within the framework of the national risk and capability assessments that EU requires in support of its security strategy. In this report, we describe the development of a scenario of a volcanic eruption on Iceland and the subsequent analysis of consequences on human health, environment and technology in Sweden. We also discuss the challenges facing Swedish society in mitigating the impacts of such an eruption.

\subsection{Previous work}

Several studies of the actual impacts on humans and environment of the Laki eruption of 1783-1784 have been carried out by studying historical documents; see, for example, 
Stothers (1996), Grattan and Pyatt (1999), Grattan and Durand (2003), Grattan et al. (2005), Thordarson and Self (2003) and Witham and Oppenheimer (2005).

Thordarson et al. (1996) arrived at an estimation of the atmospheric mass loading of gases from the Laki eruption based on measurements of gas content in the magma prior to and after eruption plus measurements of the volume of erupted material. This estimation was used as an initial value in several studies when simulating the transport of gases and the atmospheric chemistry. Simulations were performed with the purpose of analysing the eruption's possible impacts on the climate (see, for example, Highwood and Stevenson 2003; Schmidt et al. 2012) so as to determine the actual geographical concentrations of sulphur dioxide and sulphate aerosols in 1783-1784 (see, for example, Stevenson et al. 2003; Chenet et al. 2005; Oman et al. 2006), and to determine the corresponding concentrations at the present time, given different meteorological conditions and the present air pollution (see, for example, Schmidt et al. 2010, 2011). Schmidt et al. (2011) also estimated the increase in cardiopulmonary mortality due to short- and long-term exposure to the presence of $\mathrm{PM}_{2.5}$, during a future Laki-like Icelandic eruption. These estimates are based on the meteorological situations in 2003 and 2005, when the frequency of northwesterly air flow during those years was low and high, respectively.

Despite the many studies mentioned above, there is a lack of broader (multi-sector) studies that take into consideration the impacts on the entire society, including crises management on national or international levels. In 2012, the UK Government added volcanic hazard risks to the UK National Risk Register (NRR) for the first time and one of the scenarios it adopted is based on the Laki eruption of 1783-1784 (Loughlin et al. 2012). In Norway, one analysis of a Laki-like scenario has been conducted; it was published in the Norwegian national risk assessment 2014 (Direktoratet for samfunnssikkerhet og beredskap 2014). In Sweden, the Swedish Civil Contingencies Agency (MSB) included a volcanic eruption within the national risk and capability assessment, during 2013-2014. The work presented in this article was a part of that analysis.

\subsection{Methods}

For this study, we used a scenario-based approach, as practiced within the Swedish national risk and capability assessment, during 2012-2014 (see, for example, Roffey et al. 2015; Mårtensson and Hedtjärn Swaling 2016). This approach, which is described below, includes the organization of a workshop with representatives from authorities that have responsibility within crises management. Our experience from previous work is that associations with historical events increase the perceived credibility of a scenario during such workshops, and we therefore chose to develop a scenario that resembled the events of the Laki eruption. The scenario was adjusted in order to generate severe consequences for the Swedish society.

The scenario-based approach is in its entirety shown in Fig. 1. In the first stage, we developed a scenario; it described the amount of gases and particles that could reach Sweden over time during a large volcanic eruption on Iceland. This scenario was developed by considering the source terms from the volcano, the meteorological situation, the transport time through the atmosphere and the atmospheric chemistry. To some extent, we also considered historical records of impacts of the Laki eruption of 1783-1784, and the results from previous and novel simulations of the Laki eruption, to estimate the mean levels of sulphur dioxide and $\mathrm{PM}_{2.5}$ at surface level in eastern Svealand during 3 months. The reason $\mathrm{PM}_{2.5}$ is explicitly studied here is that this fraction includes respirable particles and therefore has a major impact on human health. Although present, larger particles, e.g. 




Fig. 1 The working process was divided into three parts. First, a scenario was developed; secondly, the impacts of the scenario on human health, environment and technology were analysed; and finally, the challenges for the entire society were discussed during a workshop with representatives from different authorities

$\mathrm{PM}_{10}$, have been left out of this study. The scenario was validated by comparing it to results from simulations that were run with a dispersion model that used weather data from the year of 2003 .

The impacts of the scenario on human health, environment and technology were assessed, thereafter, by using data from the literature and estimations of health consequences based on available toxicity data. The scenario and impacts on human health, environment and technology were validated by a wider panel of experts from different scientific fields during a workshop with participants representing toxicology, medicine, plant and environmental sciences and drinking water supply. After that, based on the scenario and the estimated impacts, we wrote a narrative describing the situation in eastern Svealand, a region of Sweden that was chosen to be the one most affected by the sulphur fog. The narrative focused on the ground effects of the chemical hazards released from the volcano. The societal challenges posed by impacts on air traffic were mentioned in the narrative but were not part of the analysis. ${ }^{1}$

The health impacts of released gases were estimated by calculations of ground-level concentrations and application of Acute Exposure Guideline Levels (AEGL 2010) and the US Environmental Protection Agency's Air Quality Index (AirNow 2016), but the impacts of released ash particles could not be specifically addressed, due to the absence of data on human toxicity. Instead, a rough estimate of particle-induced health effects was done by applying historical epidemiological data on massive release of anthropogenic particles, i.e. the London smog episodes of 1958-1972 (Maynard and Maynard 2002).

The scenario and narrative were presented to representatives-experts and stakeholders-of national agencies with an appointed responsibility for crisis management during societal crises. The scenario and narrative were used as a basis for discussions on what the Swedish societal reaction and response to the outlined events would be. The national agencies were MSB, the Swedish Meteorological and Hydrological Institute, the County Administrative Board of Södermanland County, the National Veterinary Institute, Region Skåne, the Sörmland County Council, the Swedish Defence Research Agency, the Public Health Agency, the National Board of Health and Welfare, the Swedish Police and Eskilstuna Municipality.

1 The societal impact of changes in air traffic resulting from volcanic eruptions was analysed by MSB after the Eyjafjallajökull ash cloud event, in 2010 (MSB 2010). 


\section{Scenario development}

In this section, we describe how the scenario was developed and on which basis. The scenario development was performed in five steps: (1) consideration of the kind of volcanic gases and solid particles that could reach Sweden during a Laki-like eruption; (2) construction of a fictitious weather situation that would allow as much volcanic pollutants as possible to reach Sweden; (3) estimation of the transport time for the pollutants, based on the chosen weather situation; (4) investigation of the chemical reactions that would take place in the atmosphere during the transport of the volcanic volatiles; and (5) based on the previous steps and on published research, estimation of the concentration of sulphur dioxide and particulate matters on the ground in Sweden during the first 3 months of the scenario. At a later stage, after the main study was performed, we had the opportunity to make our own simulations, which were used to validate our previous result. These simulations are also presented in this section.

\subsection{Volcanic pollutants that may be transported to Sweden}

As a first step, we considered what kind of volcanic gases and solid particles could be transported to Sweden during a volcanic eruption on Iceland. Volcanic degassing typically releases large quantities of water vapour and $\mathrm{CO}_{2}$, and also considerable amounts of various acidic gases, including $\mathrm{SO}_{2}, \mathrm{HCl}, \mathrm{HF}$ and $\mathrm{H}_{2} \mathrm{~S}$. An estimation of the quantities of volatiles from the Laki eruption that reached the upper troposphere and lower stratosphere, from which they were transported to Europe, has been done by Thordarson et al. (1996); see Table 1. Besides the volatiles, ash particles were also released (Thordarson et al. 1996), but there are no estimations in the literature as to what extent these were transported to Europe.

Of the volatiles released from the Laki eruption, water vapour $\left(\mathrm{H}_{2} \mathrm{O}\right)$ will not cause any harm to humans or the environment when reaching ground level and was therefore not considered in the scenario. However, it will contribute to cloud formation and to chemical reactions in the atmosphere. Carbon dioxide $\left(\mathrm{CO}_{2}\right)$ may be harmful for humans and animals in high concentrations, since it displaces oxygen (USGS 2013). On the other hand, at large distances, and under circumstances characterizing the Laki eruption, dilution and mixing processes will prevent the concentration of $\mathrm{CO}_{2}$ from reaching harmful levels in Sweden.

While water and carbon dioxide can be considered to be inert gases, the remaining acidic trace gases may undergo both homogenous (gas phase) and heterogeneous (gasliquid-solid phase) chemical and physical transformation. Hydrogen chloride $(\mathrm{HCl})$ has a short half-life in the free lower atmosphere, about 3 days (see Table 2.1 in Hobbs 2000). Now, the volcanic plume is not the free atmosphere. In particular $\mathrm{HCl}$ is efficiently absorbed into $\mathrm{H}_{2} \mathrm{SO}_{4}-\mathrm{H}_{2} \mathrm{O}$ solutions (Finlayson-Pitts and Pitts 2000). For volcanic plumes reaching the upper part of the troposphere and the stratosphere, most of the $\mathrm{HCl}$ (the

Table 1 Estimates of the mass of volatiles entering the upper troposphere and the lower stratosphere, from the Laki eruption, from June, 1783, to February, 1784 (Thordarson et al. 1996)

\begin{tabular}{lr}
\hline $\mathrm{H}_{2} \mathrm{O}$ & $183.1 \mathrm{Mt}$ \\
$\mathrm{CO}_{2}$ & $292.8 \mathrm{Mt}$ \\
$\mathrm{HCl}$ & $3.6 \mathrm{Mt}$ \\
$\mathrm{HF}$ & $8.3 \mathrm{Mt}$ \\
$\mathrm{SO}_{2}$ & $98.4 \mathrm{Mt}$ \\
\hline
\end{tabular}


concentration of $\mathrm{HCl}$ is decreased by 4 orders of magnitude) is dissolved in supercooled $\mathrm{H}_{2} \mathrm{SO}_{4}-\mathrm{H}_{2} \mathrm{O}$ droplets and is subsequently removed by wet scavenging within hours (Tabazadeh and Turco 1993). Through a competing mechanism, $\mathrm{HCl}$ (up to $25 \%$ of available $\mathrm{HCl}$ ) may bind to ash particles at the high-temperature phase of the plume (Ayris et al. 2014).

Hydrogen fluoride (HF) is by itself very toxic, but dilution and removal processes generally hinder HF from being regionally transported in concentrations that are detrimental to human health. However, the surface plume associated with the Laki 1783 eruption caused a significant toxic response (fluorosis) on Iceland, killing $75 \%$ of grazing livestock. Our assessment is that $\mathrm{HCl}$ and $\mathrm{HF}$ cannot be transported to Sweden in toxic concentrations when released in the quantifies as shown in Table 1, which is supported by the fact that there were no clear reports in 1783-1784 of grazing livestock outside Iceland with symptoms characteristic of fluorine poisoning (Thordarson and Self 2003). However, an eruption more explosive than Laki would produce much more ash and in that case fluorine could be attached to the ash particles and therefore transported to Scandinavia in hazardous concentrations.

Sulphur dioxide $\left(\mathrm{SO}_{2}\right)$ can be transported long distances. During the transport, a part of the $\mathrm{SO}_{2}$ will be oxidized and converted to sulphuric acid $\left(\mathrm{H}_{2} \mathrm{SO}_{4}\right)$. How large a partition is converted depends on several factors, such as time, temperature and amount of ozone and $\mathrm{OH}-$. Both $\mathrm{SO}_{2}$ and $\mathrm{H}_{2} \mathrm{SO}_{4}$ are harmful to humans and the environment in high concentrations, together constituting the main potential hazards in the scenario. Analysis of their concentrations at ground level in Sweden was therefore performed separately (see Estimated concentrations of $\mathrm{PM}_{2.5}$ and $\mathrm{SO}_{2}$ ). Dispersion of solid ash particles would constitute an additional hazard, both by the inherent toxicity of the particles themselves and as a combined toxic entity when bound to sulphur compounds in the atmosphere (IVHHN 2013). The sulphuric acid would be partly neutralized, mainly by ammonia $\left(\mathrm{NH}_{3}\right)$, to form the salt, ammonium bisulphate $\left(\mathrm{NH}_{4} \mathrm{HSO}_{4}\right)$ and eventually ammonium sulphate $\left[\left(\mathrm{NH}_{4}\right)_{2} \mathrm{SO}_{4}\right]$. Given the very high concentration of acidic gases, it is, however, unlikely that more than a minor fraction of sulphuric acid would be neutralized within timescales required for transport to Sweden.

\subsection{Estimation of unfavourable weather conditions}

In the scenario development, we aimed at constructing a weather scenario providing the highest possible concentrations of volcanic pollution for eastern Svealand. To do that, we are dependent on a stable blocked high-pressure weather pattern much like the summer of 1783. In our scenario, we chose the 23 May as the time for the first volcanic eruption instead of the 8 June that was the date of the year for the real Laki eruption. The reason for this was to maximize the impacts of the pollutants during the sensitive biological growth period in our scenario.

Hence, we assumed a high-pressure situation as depicted in Fig. 2, where the figure to the left is the situation at the onset of the eruption and the figure to the right is the situation 6 weeks later, when we suppose that Sweden experiences the highest concentrations of volcanic pollution (see Estimated concentrations of $\mathrm{PM}_{2.5}$ and $\mathrm{SO}_{2}$ ). The dynamics around a high-pressure system are such that winds at higher altitudes rotate clockwise and subside in a spiral inwards to the centre of the high-pressure system. Thus, erupted gases at high altitudes will eventually be trapped in inversions and eventually be transported down to the ground and, together with gases transported more directly (at low-medium altitude) in a 

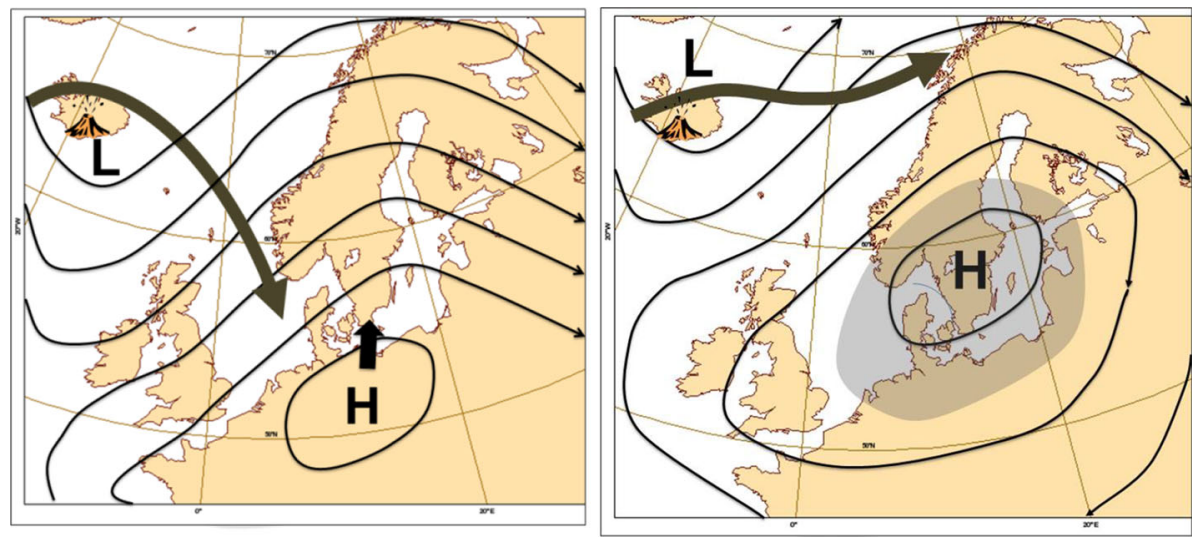

Fig. 2 Weather situation in the constructed scenario at the onset of the volcanic eruption on the 23 May, in Iceland (left), and on the 14 July, when the highest concentrations are recorded in eastern Svealand (right). During the period between the images, the centre of the anticyclone moves from the northern parts of Germany to Svealand. The surface winds move clockwise around the high-pressure centre and are weak in the centre. The gas cloud from the eruption reaches altitudes between 8 and $12 \mathrm{~km}$. The predominant wind direction at these levels is illustrated by the thick black arrows starting in and around Iceland. The grey shaded area (right) is the most affected area in the scenario

north-westerly flow from Iceland, contribute to the high concentrations we use in our scenario.

From Thordarson and Self (2003), we know that large areas experienced the volcanic gases with fluctuating concentration levels over time during the Laki episode. The size of the area covered by thick low haze in the summer of 1783 stretched from south-eastern England down to the Alps. The grey shaded area in Fig. 2 (right) illustrates the area we assume will be most affected by the haze in our scenario.

Furthermore, in order to make a more challenging scenario, we introduced relief from the gases in eastern Svealand, for 2 weeks in late June, by letting the centre of the anticyclone move eastward to southern Finland. After that we let the gases return in early July at slightly lower levels. Finally, we wanted to explore the consequences of a heavily acidic precipitation and therefore added a quick breakdown of the anticyclone with strong cold fronts with heavy rain showers that washed out the volcanic gases and produced an acid rain. We were aware that the addition of those details lowered the overall probability of the scenario. The probability of a persistent anticyclone event like the one described is low. High-pressure blockings occur all year round with a slightly higher frequency during spring and winter. In the scenario, the blocking lasts 4-5 weeks, which is a rare event, but not completely unlikely. ${ }^{2}$

The weather situation depicted in this section was used when calculating the concentrations of sulphur dioxide and particulate matter over time, and when writing the scenario narrative (as described in "Appendix").

\footnotetext{
2 An investigation based on 42 years of data found 17 persistent high-pressure blocking events lasting over 25 days confined to the area over Atlantic and Western Europe (Diao et al. 2006), where nine of those were during spring and summer. The longest summer-blocking in this 42-year dataset lasted 29 days.
} 


\subsection{Transport time for pollutants to reach Sweden}

Since the conversion of $\mathrm{SO}_{2}$ into $\mathrm{H}_{2} \mathrm{SO}_{4}$ is a function of time, the transport time for the volcanic pollution until it reaches the ground in Sweden must be estimated. The transport can be divided into two parts: the horizontal transport through the upper troposphere and the lower stratosphere and the vertical transport through the subsidence.

In order to investigate typical horizontal transport times from Iceland to Sweden, a trajectory analysis using the modelling system HYSPLIT4 (Draxier and Hess 1998) was performed. For this purpose, $240 \mathrm{~h}$ forward trajectories were calculated at three different altitudes every $4 \mathrm{~h}$ from 2004 to 2010 . The trajectory location, altitude and transport time were mapped on a $0.75^{\circ}$-by $-4^{\circ}$ grid between $0-90^{\circ}$ and $0-360^{\circ}$, centred on Laki, Iceland. This allows for at least a qualitative assessment of typical transport patterns and transport times from Laki to Scandinavia. As can be seen in Fig. 3, the transport time of air masses released at 10,000 $\mathrm{m}$ above Laki (the mean emission height estimated by Thordarson and Self 2003) was in the order of 3-4 days during 2004-2010, when the wind transported the air masses from Iceland to Sweden and at the same time descended to a height of 8-9000 $\mathrm{m}$ above ground. This is the yearly average and useful for finding the baseline for horizontal transport times. For real events, the actual weather situation is what determines the transport time. We know that gases from volcano eruptions can reach Scandinavia in a few days in favourable weather conditions.

For our scenario we also have to consider the subsidence the gases undergo in the highpressure system (the vertical transport). Assuming a subsidence rate of $1 \mathrm{~cm} / \mathrm{s}$, with local deviations up to $5 \mathrm{~cm} / \mathrm{s}$, the vertical transport time from 8 to $9000 \mathrm{~m}$ to the ground was estimated to be about 6 days. By adding the horizontal transport time from Fig. 3a of about 3-4 days, the total transport time from the source (Laki) to ground (in Scandinavia) was determined to be 10 days. This figure is used in the scenario and is consistent with what the historical record of the Laki eruption shows (Thordarson and Self 2003, Figure 4c). The figure is also consistent with the transport times given in (Witham et al. 2015, Figure 6.7). Although this reference points to a large variability of transport times, between 2 and 42 days, for a Laki-like eruption, it is likely that the shortest transport times are related to transport in the lower part of the troposphere and the longest are due to a meteorological condition bringing the pollutants along a very indirect route.

During the 10 days of transportation from Iceland to Sweden, the content of the volcanic pollution will change. The transport efficiency of tephra particles is strongly dependent on emission height and meteorological conditions, but also on the particle size, morphology and chemical composition. Large, coarse-mode particles $(>1 \mu \mathrm{m})$ will likely sediment out rapidly from the plume, while smaller particles, in the sub-micrometre range, will have a significantly longer atmospheric residence time. The main mass-removal mechanism in this size range is wet removal, especially favouring removal of water soluble components.

\subsection{Estimated concentrations of $\mathbf{P M}_{2.5}$}

To create credible assumptions of ground concentrations for a Laki-like eruption, we took advantage of a previous study by Schmidt et al. (2011) where a Laki-like eruption was simulated with dispersion models driven by actual weather. In that study, the spatial mass distribution of $\mathrm{PM}_{2.5}$ was calculated from a Laki-style eruption based on the meteorological situations in the years 2003 and 2005. The authors did not, however, explicitly state 

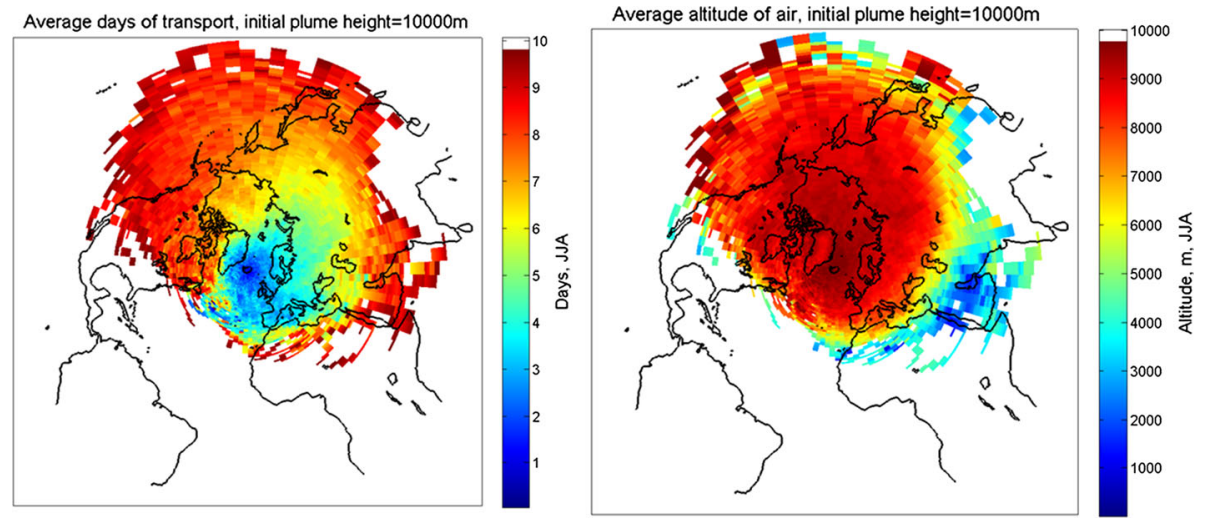

Fig. 3 (Left) Average horizontal transport time for air parcels emitted at $10000 \mathrm{~m}$, years 2004-2010. Colour coding indicates the average transport time in the horizontal to each grid point of the map. (Right) Average altitude of the air parcels

whether the $\mathrm{PM}_{2.5}$ consisted of sulphuric acid aerosols, solid particles or a mix of them. We therefore assumed that the particulate matter (PM) consists of both sulphuric acid aerosols and of sulphur compounds adsorbed to solid ash particles. ${ }^{3}$ Schmidt et al. (2011) showed that the highest average concentration of volcanic $\mathrm{PM}_{2.5}$ during the three first simulated months occurred in Scotland at a level of $30 \mu \mathrm{g} / \mathrm{m}^{3}$. Since the meteorological situation chosen for our scenario was meant to be worse than the weather situations in 2003 and 2005, we assume it is plausible that in our scenario a similar mean concentration would occur in Sweden, even if the distance from Iceland is longer to Sweden than to Scotland.

Schmidt et al. (2011) did not estimate the local time variance of the concentration of $\mathrm{PM}_{2.5}$ for horizontal scales below about $100 \mathrm{~km}$. One of their results, however, shows that the peak value of the mean concentration for all of Europe is 3-4 times the mean value during 3 months. ${ }^{4}$ We assumed the same ratio between the peak and mean values in our scenario, even if it would be reasonable to suppose that the variance in the smaller area of eastern Svealand would be higher. Based on these assumptions, we constructed a graph showing the 24-h mean $\mathrm{PM}_{2.5}$ concentration in eastern Svealand over time, as illustrated in Fig. 4. The graph is based on several assumptions; for example, the inflow of $\mathrm{PM}_{2.5}$ is dependent on the mass loading and the timing of the different eruption episodes; there exists an outflow of $\mathrm{PM}_{2.5}$ from the high pressure to the surroundings; and the high pressure, including the sulphur fog, moves to Finland at the end of June and comes back in the middle of July. We also added the present background level of 5-10 $\mu \mathrm{g} / \mathrm{m}^{3} \mathrm{PM}_{2.5}$ in the studied area, ${ }^{5}$ mostly comprised of solid particles.

Just like visibility in fog, the spatial distribution of gases close to the ground at any given time can vary considerably over short distances, since it is determined by the

\footnotetext{
${ }^{3}$ Many researchers have assumed that sulphate aerosols produced in the eruption consist of $75 \mathrm{wt} \% \mathrm{H}_{2} \mathrm{SO}_{4}$ and $25 \mathrm{wt} \% \mathrm{H}_{2} \mathrm{O}$; see, for example, Chenet et al. 2005; Grattan et al. 2005; Oman et al. 2006; Scmidt et al. 2010 .

4 The European mean $\mathrm{PM}_{2.5}$ concentration from the volcano's eruption has a peak of $62.1 \mu \mathrm{g} / \mathrm{m}^{3}$ in the 2003 simulation and of $80.9 \mu \mathrm{g} / \mathrm{m}^{3}$ in the 2005 simulation, while the mean value during the first 3 months is $23 \mu \mathrm{g} / \mathrm{m}^{3}$.

5 http://miljobarometern.stockholm.se/key.asp?mo=2\&dm=2\&nt=3 (2013-07-01).
} 


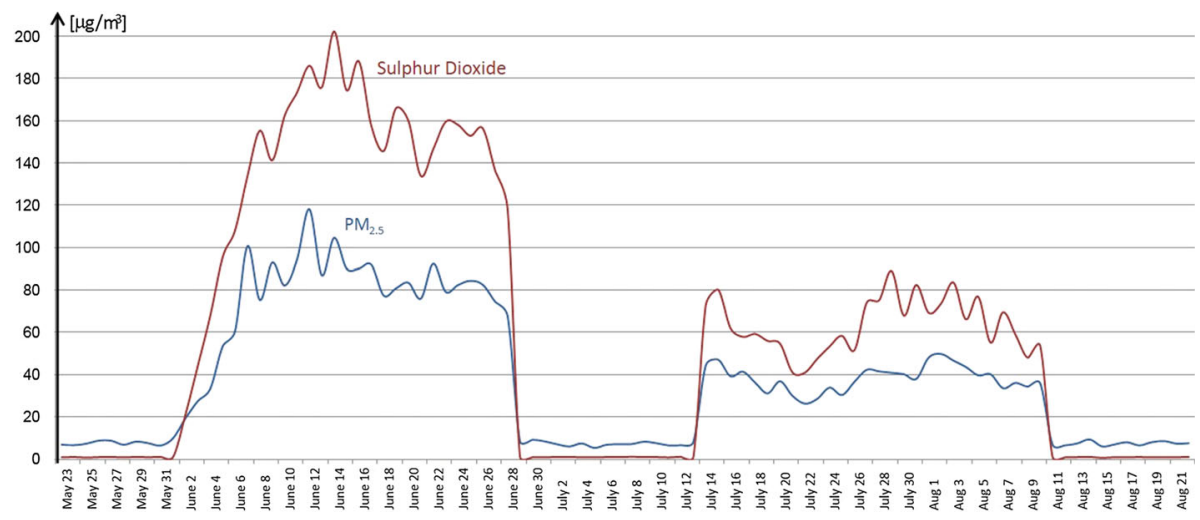

Fig. 4 Mean concentrations of PM2.5 (blue graph) and of sulphur dioxide (red graph) at surface level in eastern Svealand during the first 3 months of the eruptions (23 May until 22 August)

interaction between the local terrain and the stability of the atmosphere. ${ }^{6}$ The latter depends on the daily evolution of the planetary boundary layer and the associated modification of the vertical temperature gradients in this type of high-pressure situations. This process determines the strength and height of ground- and low-level inversions where gases will accumulate into high concentrations. We assumed that the highest concentrations locally during short time periods (up to 1 day) could be five times as high as the mean value for the entire area (eastern Svealand). Hence, the highest concentration of $\mathrm{PM}_{2.5}$ in the scenario was estimated to be $600 \mu \mathrm{g} / \mathrm{m}^{3}$, five times the peak value of $120 \mu \mathrm{g} / \mathrm{m}^{3}$, which in our scenario occurred in the town of Eskilstuna on the 14 June. Our assumptions about peak concentrations are consistent with the Laki-like eruption studies presented in Witham et al.(2015; see in particular Section 6.7.3), where indeed even higher concentrations were observed.

\subsection{Estimated concentrations of $\mathrm{SO}_{2}$}

So far, we have proposed a maximum-effect scenario for the spatial and chronological variation of the concentration of $\mathrm{PM}_{2.5}$ in eastern Svealand, mainly based on the result of Schmidt et al. (2011). However, Schmidt et al. (2011) did not present any figures for the $\mathrm{SO}_{2}$ concentrations. But since $\mathrm{SO}_{2}$ has an impact on both human health and vegetation, it was necessary, as a next step, to estimate the concentrations of $\mathrm{SO}_{2}$ transported to Europe.

There are different estimations in the literature of how large the proportion of the sulphur dioxide was that was transported undisturbed from Iceland to Europe during the 1783 Laki eruption. Thordarson and Self (2003) and Chenet et al. (2005) assumed that all $\mathrm{SO}_{2}$ released was converted to sulphuric acid aerosols before it reached Europe. Oman et al. (2006) estimated, based on simulation results, that approximately $30-35 \%$ of the $\mathrm{SO}_{2}$ gas was transported undisturbed to Europe during 1783-1784, while Stevenson et al. (2003) estimated the corresponding figure, also based on simulations, to $70 \%$. Schmidt et al. (2010) also showed that the ratio between the $\mathrm{SO}_{2}$ and $\mathrm{SO}_{4}$-aerosol concentrations varied substantially at different latitudes during the Laki eruption, in 1783.

\footnotetext{
${ }^{6}$ There is literature on the structure of small-scale geospatial variation of gases (concentrations). However, those publications are predominantly studies of local air quality, where the source is on the ground itself (highways, industrial plants, or entire cities), and the results cannot be directly transferred to this situation.
} 
The literature in atmospheric chemistry shows a large variation in lifetimes of volcanic $\mathrm{SO}_{2}$ in the troposphere. In terms of the $\mathrm{SO}_{2}$ to $\mathrm{H}_{2} \mathrm{SO}_{4}$ transformation, if first-order kinetics are assumed, the rate constant for $\mathrm{SO}_{2}$ removal, $\lambda$, has been observed to lie in the interval $1.9 \times 10^{-7}-5.4 \times 10^{-5} / \mathrm{s}$ in different volcanic plumes at different altitudes (Oppenheimer et al. 1998). ${ }^{7}$ The value will strongly depend on season, solar radiation, relative humidity, temperature and initial plume concentration. The observations were made from in total nine volcano eruptions, none of them on Iceland. The lowest observed value on $\lambda$ correspond to that $85 \%$ of the $\mathrm{SO}_{2}$ gas will be transported undisturbed during the 10 days we have assumed in our scenario, while the largest value on $\lambda$ in practice will result in an oxidation of all $\mathrm{SO}_{2}$.

Since there is no obvious agreement in the literature on how large the proportion of $\mathrm{SO}_{2}$ is that will reach Europe undisturbed, we had to make our own estimation of reasonable concentrations. Since the Laki eruption in 1783 damaged the vegetation in ways that indicated high $\mathrm{SO}_{2}$ concentrations, at least locally, we estimated the $\mathrm{SO}_{2}$ concentrations in our scenario to be well above the threshold for damage to the vegetation, but below concentrations that would lead to a large number of human fatalities, which is $60 \mu \mathrm{g} / \mathrm{m}^{3}$ as a mean value during the 3-month scenario. If we assume that all $\mathrm{PM}_{2.5}$ particles would be liquid aerosols consisting of $75 \mathrm{wt} \% \mathrm{H}_{2} \mathrm{SO}_{4}$ and $25 \mathrm{wt} \% \mathrm{H}_{2} \mathrm{O}$, which seems to be a common assumption in the literature, in our scenario this would correspond to approximately $20 \%$ transformation of $\mathrm{SO}_{2}$ to $\mathrm{H}_{2} \mathrm{SO}_{4}$, while $80 \%$ partition of the $\mathrm{SO}_{2}$ that was transported to ground level in Sweden would have arrived undisturbed. ${ }^{8}$ The $\mathrm{SO}_{2}$ concentration over time in eastern Svealand was calculated in an equivalent way as the concentration for $\mathrm{PM}_{2.5}$ and is shown in Fig. 4. The highest local 24-h exposure to $\mathrm{SO}_{2}$ was estimated as $1100 \mu \mathrm{g} / \mathrm{m}^{3}$, which is five times the peak value for all of eastern Svealand, and depicted in the scenario as occurring in Eskilstuna on the 14 June.

\subsection{Validation of the concentrations and rate constant for $\mathrm{SO}_{2}$ removal in the scenario}

After our study was finished and reported to the Swedish Civil Contingencies Agency, we had the opportunity to use the PELLO dispersion model (Lindqvist 1999) to make our own simulation of the atmospheric transport of $\mathrm{SO}_{2}$ from a fictive volcanic eruption on Iceland to ground level in Europe. The simulation used weather data from the summer of 2003, which was an unusually warm summer, since a high-pressure blocking dominated the weather pattern over continental Europe. It will also make possible a comparison with the work of Schmidt et al. (2011), who also used 2003 in their work. The dispersion of $\mathrm{SO}_{2}$ was simulated in accordance with the Laki eruption episodes as described in Thordarson and Self (2003). Since PELLO does not include any atmospheric chemistry, the result in terms of concentrations of the gases transported to Europe were presented in $\mathrm{SO}_{2}$ equivalents, parts of which were supposed as having been transformed to $\mathrm{H}_{2} \mathrm{SO}_{4} .{ }^{9}$ The result was presented on a grid with a resolution of $2.5^{\circ}$ by $2.0^{\circ}$ latitude/longitude, so as to be comparable to the size of the area of eastern Svealand that was used in our scenario.

\footnotetext{
$7 \mathrm{SO}_{2}=\mathrm{SO}_{2, \text { int }} \mathrm{e}^{(-\lambda \mathrm{t})}$ where $\mathrm{SO}_{2}$ is the remaining $\mathrm{SO}_{2}$ at time $t, \mathrm{SO}_{2, \text { ini }}$ is initial concentration and $\lambda$ is the rate constant.

8 These figures are based on the assumption that 1 weight unit of $\mathrm{SO}_{2}$ corresponds to 1.53 weight units of $\mathrm{H}_{2} \mathrm{SO}_{4}$ and to 2.05 weight units of $\mathrm{PM}_{2.5}$.

9 One mass unit of $\mathrm{SO}_{2}$ was supposed as corresponding to 1.53 mass units of $\mathrm{H}_{2} \mathrm{SO}_{4}$ and to 2.04 mass units of liquid $\mathrm{PM}_{2.5}$ consisting of $75 \mathrm{wt} \% \mathrm{H}_{2} \mathrm{SO}_{4}$ and $25 \mathrm{wt} \% \mathrm{H}_{2} \mathrm{O}$.
} 
The weather in 2003 and the weather situation in our scenario are both rather extreme, but differ with respect to timing, position and length of the high-pressure blocking, ${ }^{10}$ so it is not meaningful to compare the results in detail. It is, however, of interest to compare them with respect to transportation time, duration of the sulphur fog, mean concentrations of $\mathrm{SO}_{2}$ and highest peak concentrations. The simulations showed that the transport time varied between 6 and 10 days, dependent on the transportation altitude, which was in accordance with our assumptions. However, the trajectories responsible for the highest ground concentration originated from lower levels than anticipated from Thordarson and Self (2003). The maximum concentration of $\mathrm{SO}_{2}$ equivalents at ground level in Europe (in an area corresponding to that of eastern Svealand) occurred in the area around Berlin and was $216 \mu \mathrm{g} / \mathrm{m}^{3}$ (daily mean). The corresponding figure in our scenario was $320 \mu \mathrm{g} / \mathrm{m}^{3}$, which is in the same order of magnitude. When looking at the result with a higher resolution, $0.1^{\circ}$ by $0.1^{\circ}$ latitude/longitude (hourly mean), the largest peak was about five times the largest peak in the simulations with less resolution, which is in agreement with our assumptions.

The duration of the sulphur fog in the simulation (days when the concentrations of $\mathrm{SO}_{2}$ equivalents were higher than normal) was typically 2-3 weeks in the most affected areas, which is considerably shorter than what we assumed in our scenario, where we chose an extremely persistent blocking situation. The mean concentration of $\mathrm{SO}_{2}$ equivalents in the worst affected area in the simulation (Sanok, Poland, during 18 days, $55 \mu \mathrm{g} / \mathrm{m}^{3}$ ) was slightly lower than the mean concentration in our scenario (eastern Svealand, Sweden, 90 days, $86 \mu \mathrm{g} / \mathrm{m}^{3}$ ). Altogether, the simulation results verified that the concentrations used in our scenario were high compared to the weather situation in 2003, but still credible if assuming an unfavourable scenario. A disadvantage of the PELLO dispersion model is that it does not take atmospheric chemical processes into account; hence, the simulation results only gave us a verification of the concentrations with respect to $\mathrm{SO}_{2}$ equivalents, but left unanswered the question of how large a part of the $\mathrm{SO}_{2}$ was transported undisturbed and how large a part was converted to $\mathrm{H}_{2} \mathrm{SO}_{4}$. The ratio between $\mathrm{SO}_{2}$ and $\mathrm{SO}_{4}$ can, however, be compared to those in the sulphur fog in the northern parts of Scandinavia resulting from the Holuhraun eruption in 2014-2015. Using observed concentrations, as reported by Jakobsson et al. (2016), of $\mathrm{SO}_{2}$ and $\mathrm{SO}_{4}$ from the EMEP stations in Hurdal, Norway, and Bredkälen, Sweden, in September 2014, we estimate this ratio to be 2:1 in Bredkälen and 1:2 in Hurdal. This indicates that the ratio $2: 1$ used in our scenario would be possible, even if it implies unusually low conversion of $\mathrm{SO}_{2}$ to $\mathrm{SO}_{4}$.

To further corroborate our scenario, we note that the Swedish Meteorological and Hydrological Institute (SMHI), in collaboration with FOI, has simulated $\mathrm{SO}_{2}$ and $\mathrm{SO}_{4}$ concentration levels for Sweden for a Laki-style eruption, using an unfavourable weather situation for northern Scandinavia for the autumn of 2015 (high-pressure blockage over northern Sweden for most of the period of August 12 -September 12, 2015; Persson et al. 2016). Using the Eulerian dispersion model, $\mathrm{MATCH}$, concentrations of $\mathrm{SO}_{2}$ and $\mathrm{SO}_{4}$ were estimated for northern, central and southern Sweden. The maximum 3-h averages of $\mathrm{SO}_{2}$ and $\mathrm{SO}_{4}$ were estimated at 180 and $55 \mu \mathrm{g} / \mathrm{m}^{3}$, respectively, for northern Sweden, 180 and $60 \mu \mathrm{g} / \mathrm{m}^{3}$, respectively, for central Sweden, and 140 and $100 \mu \mathrm{g} / \mathrm{m}^{3}$, respectively, for southern Sweden. Converting the $\mathrm{SO}_{4}$ concentrations to a $\mathrm{PM}_{2.5}$ assumed to consist of $75 \mathrm{wt} \% \mathrm{SO}_{4}$ and $25 \mathrm{wt} \% \mathrm{H}_{2} \mathrm{O}$, they find the maximum 3-h average of $\mathrm{PM}_{2.5}$ to be $140 \mu \mathrm{g} /$ $\mathrm{m}^{3}$ for southern Sweden (and slightly lower for the other regions). The corresponding

10 The summer (especially August) of 2003 was, in many places over continental Europe, the warmest on record since the sixteenth century, but over most of Scandinavia August was slightly cooler than normal. 
4-month average of $\mathrm{PM}_{2.5}$ is given as $22-24 \mu \mathrm{g} / \mathrm{m}^{3}$ and for $\mathrm{SO}_{2}$ as $20 \mu \mathrm{g} / \mathrm{m}^{3}$. Unlike the PELLO simulations referred to above, MATCH contains a full description of the relevant atmospheric sulphur chemistry. It is, however, interesting to note that both the PELLO and the MATCH simulations show that there is a much variance in the concentrations, with sharp peaks (bursts) of high concentrations intermitted by periods with very low concentrations of pollutants. This stands in contrast to our scenario (see Fig. 4), where we have assumed that the elevated concentrations remain for prolonged periods.

\section{Impacts on human health, environment and technology}

The ground concentrations of $\mathrm{PM}_{2.5}$ and of sulphur dioxide shown in Fig. 4 were presented in a workshop with representatives from national authorities, in order to make an assessment of the overall challenges for society. As a complement to the graphs, a narrative was developed and presented during the workshop, describing the course of events and possible impacts of the pollutants over time (see "Appendix"). These impacts were based on literature studies of observations from volcanic eruptions and observations of other occasions with heavy air pollution, and on available literature data on the effects of estimated ground concentrations of the identified pollutants. In addition, a panel of experts in the fields of toxicology, medicine, plant and environmental sciences reviewed the results of the study and provided scientific support to the concluding remarks and pinpointed uncertainties in the assessments. Below, we present the estimated impacts of the pollutants on human health, environment and technology, as described in the scenario.

\subsection{Impacts on human health}

Due to the high toxicity, we estimated that $\mathrm{SO}_{2}$ would be the main toxic component among the sulphur compounds in the volcanic eruption, i.e. that sulphates and sulphuric acid would have relatively low impact on human health. To the impact of $\mathrm{SO}_{2}$ gas, we added a contribution of particles $\left(\mathrm{PM}_{2.5}\right)$, partly consisting of respirable solid ash, to the health impact calculations. The solid particle fraction would likely have a core of minerals and glass, and due to fusion with liquid aerosols the surface would to some extent be coated by sulphuric compounds. Since solid particles are considered to be harmful to human health, we also decided to include an estimation of toxicity of the solid core. We assessed the health consequences of the sulphur dioxide and aerosol particles in two cases: the 24-h peak exposure in the city of Eskilstuna and the 3-month period in the entire region of eastern Svealand. The consequences are summarized below and given in Table 2. According to the defined acute exposure guidelines levels (AEGL), the peak value of $1100 \mu \mathrm{g} / \mathrm{m}^{3}$ in Eskilstuna would reach AEGL-1 after 10-min exposure, meaning that the general population, especially susceptible individuals, could experience notable, although non-disabling, discomfort, irritation or certain asymptomatic non-sensory effects (AEGL 2010). The prolonged exposure time of $24 \mathrm{~h}$ would lead to the risk that a significant proportion of the population would experience irreversible adverse health effects, or an impaired ability to escape, but with few fatal casualties. According to the US Environmental Protection Agency Air Quality Index, the 24-h exposure of $1100 \mu \mathrm{g} / \mathrm{m}^{3} \mathrm{SO}_{2}$ would lead to significant increase in respiratory symptoms, such as wheezing and shortness of breath, for people with asthma, as well as aggravation of heart or lung disease (AirNow 2016). The result of a calculation of the casualty outcome indicated that an estimated 54\% 
Table 2 Summary of the supposed impacts on human health in the scenario

\begin{tabular}{|c|c|c|c|c|}
\hline Substance & Period & Critical levels & $\begin{array}{l}\text { Max levels in } \\
\text { the scenario } \\
\left(\mu \mathrm{g} / \mathrm{m}^{3}\right)\end{array}$ & Potential impacts human health \\
\hline \multirow[t]{2}{*}{$\mathrm{SO}_{2}$} & $\begin{array}{l}\text { 8-h peak } \\
\text { exposure }\end{array}$ & $\begin{array}{l}520 \mu \mathrm{g} / \mathrm{m}^{3} \\
(\mathrm{AEGL}-1)\end{array}$ & 1100 & $\begin{array}{l}\text { A significant proportion of the population } \\
\text { would experience irreversible adverse } \\
\text { health effects, or an impaired ability to } \\
\text { escape, but with few fatal casualties (based } \\
\text { on AEGL 2010) }\end{array}$ \\
\hline & $\begin{array}{l}\text { 3-month } \\
\text { period }\end{array}$ & Not defined & 60 & $\begin{array}{l}\text { Probably non-disabling and transient irritation } \\
\text { of airways and eyes in a small proportion of } \\
\text { the population }\end{array}$ \\
\hline \multirow[t]{2}{*}{$\mathrm{PM}_{2.5}$} & $\begin{array}{l}\text { 24-h peak } \\
\text { exposure }\end{array}$ & $\begin{array}{l}\text { Unknown for } \\
\text { volcanic ash } \\
\text { particles }\end{array}$ & 600 & $\begin{array}{l}\text { Great uncertainties in estimates of toxic } \\
\text { outcomes }\end{array}$ \\
\hline & $\begin{array}{l}\text { 3-month } \\
\text { period }\end{array}$ & $\begin{array}{l}\text { Unknown for } \\
\text { volcanic ash } \\
\text { particles }\end{array}$ & 30 & $\begin{array}{l}\text { Probably very small increase in irreversible } \\
\text { health effects and death rates }\end{array}$ \\
\hline
\end{tabular}

of the population would feel transient irritation in upper airways and eyes, with occasional lachrymation. Approximately 10\% would suffer from more pronounced airway irritation, and some individuals would experience obstruction of breathing. Persistent injuries and hospitalization may occur, particularly among children, elderly and individuals with respiratory diseases such as asthma and chronic obstructive pulmonary disease (COPD).

For the entire region of eastern Svealand, two longer episodes of moderately increased elevated $\mathrm{SO}_{2}$ levels would occur. Based on the regional mean $\mathrm{SO}_{2}$ levels (see Fig. 4), both episodes are estimated to produce non-disabling and transient irritation of airways and eyes in a small proportion of the population $(<0.1 \%)$. In a historical perspective, the levels during the first episode (1-28 June) would be slightly above the average $\mathrm{SO}_{2}$ concentrations in a European urban environment during the 1960s, and the second episode (12 July12 August) would be similar to the corresponding values in the 1970s (City of Stockholm 2016). The minor health outcome in the highly populated region of eastern Svealand (with a population of 4 million people), despite the relatively long 1-month episodes of increased levels, is due to the relatively low impacts of exposure time and high influence of concentration in the toxicity estimates of $\mathrm{SO}_{2}$ (CPR 16E 1992).

The exposure to liquid aerosols and solid ash particles would likely produce health impacts superimposing the effects of the $\mathrm{SO}_{2}$ gas. Due to the chemical and physical complexity of volcanic particles, a definite toxicity estimate analogous to the estimation of $\mathrm{SO}_{2}$ toxicity could not, however, be calculated. The uncertainties in particle composition therefore required a different approach for the assessment of health outcome. Instead of direct toxicity estimates, we took advantage of the well-documented epidemiological studies of air pollution episodes in urban environments. According to the WHO Global Burden of Disease (GBD) database, the two 1-month episodes of moderate increase of $\mathrm{PM}_{2.5}$ correspond to the most extreme mean concentrations experienced by populations in the globally most-polluted areas of China and India (Brauer et al. 2016). The 24-h episode with peak $\mathrm{PM}_{2.5}$ concentrations of $600 \mathrm{mg} / \mathrm{m}^{3}$ exceeds the highest measured annual average concentration in the assembled GBD database. It should be noted, though, that the accuracy of using exposure data of ambient particulate matter air pollution is hampered by 
the limitation that such data are derived from industrial production and burning of fossil fuels. In general, such particles have a core of hydrocarbons, e.g. soot, which differs from the mineral and glass core of volcanic ash particles. During transportation in the atmosphere, both anthropogenic and volcanic particles are further modified by adsorption of gases and deposition of liquid aerosols.

Furthermore, it is shown that ambient ultrafine and $\mathrm{PM}_{2.5}$ aerosol particles tend to agglomerate at high mass concentration, forming larger particles with lower surface area per mass unit (Maynard and Maynard 2002). Since surface area rather than mass concentration is related to particle-induced toxicity, such agglomeration would lead to a nonlinear dose-response relationship, with declining increase in toxicity at high particle mass concentrations. By applying the particle agglomeration model on epidemiological data from the London smog episodes 1958-1972, Maynard and Maynard (2002) could provide an explanation for the declined increase in excess daily mortality at mass concentrations above $250 \mu \mathrm{g} / \mathrm{m}^{3}$. Due to the consideration of exposures at very high particle concentrations in the study by Maynard and Maynard, we decided to apply their model to estimate lethal outcomes of the volcanic particles.

Applying this model to the volcanic scenario would result in excess death rates of approximately two individuals in the city of Eskilstuna (with 100,000 residents), during the 24-h episode with peak $\mathrm{PM}_{2.5}$ concentration of $600 \mu \mathrm{g} / \mathrm{m}^{3}$ and a daily death rate of 40 and 20 individuals in the whole region of eastern Svealand, during the two 1-month episodes with moderate increase in particle concentrations (mean concentration of 80 and $40 \mu \mathrm{g} / \mathrm{m}^{3}$, respectively). In total, this would result in approximately 1800 fatalities in the region of eastern Svealand during the 3-month period of the volcanic eruption. These numbers are consistent with the calculations of death rates in a scenario of Laki-like eruption across Europe developed by Schmidt et al. (2011). It seems, thus, that the particle component of the volcanic exhaust may result in many more casualties through long-term ashfall at moderate concentrations in large regions than the short-term exposure of high concentrations in small areas. In scenarios of high particle exposures, the number of exposed individuals rather than peak air concentration has the strongest impacts on societal health, in contrast to the sulphur dioxide gas component.

\subsection{Impacts on the environment}

Camuffo and Enzi (1995) have shown that vegetation can be severely damaged by volcanic pollutants. During the Laki eruption of 1783, many observations of burned vegetation, plants that had lost their greenness and trees with withered leaves were reported (Thordarson and Self 2003). In some places, large parts of the 1783 harvest were destroyed. That was probably aggravated by parasites that attacked the damaged crop and by the heat and drought that occurred at the same time. Stevenson et al. (2003) argue that it was the sulphur dioxide, $\mathrm{SO}_{2}$, not the $\mathrm{PM}_{2.5}$ aerosols, which had the large negative impacts on the vegetation in Europe during the Laki eruption. The impacts on the environment that the scenario supposes are described below and summarized in Table 3.

Bertills and Lövblad (2002) claim that the critical load (i.e. what nature can tolerate) of $\mathrm{SO}_{2}$ is $20 \mu \mathrm{g} / \mathrm{m}^{3}$, as an annual mean for vegetation in general, and $30 \mu \mathrm{g} / \mathrm{m}^{3}$ for agriculture. According to the World Bank Group (WBG 1998), sensitive plants can be affected by an 8 -h exposure to $\mathrm{SO}_{2}$ if the concentration is $500 \mu \mathrm{g} / \mathrm{m}^{3}$ or higher. If the exposure lasts for an entire growing season, a concentration of $40 \mu \mathrm{g} / \mathrm{m}^{3} \mathrm{SO}_{2}$ is enough to introduce damage. The entire plants do not necessarily die, but acute leaf damage may occur. The symptoms vary between different species and depend on factors such as age, the time in the 
Table 3 Summary of the supposed environmental impacts in the scenario

\begin{tabular}{|c|c|c|c|c|}
\hline Substance & Period & Critical load & $\begin{array}{l}\text { Max levels in } \\
\text { the scenario }\end{array}$ & $\begin{array}{l}\text { Potential impacts on the } \\
\text { environment }\end{array}$ \\
\hline \multirow[t]{3}{*}{$\mathrm{SO}_{2}$} & Annual mean & $20-30 \mu \mathrm{g} / \mathrm{m}^{3}$ & & \multirow{3}{*}{$\begin{array}{l}\text { Many plants will die in the mos } \\
\text { affected areas, harvests and } \\
\text { forage will be partly destroyed } \\
\text { (based on Bertills and Lövblad } \\
\text { 2002; WBG 1998) }\end{array}$} \\
\hline & $\begin{array}{l}\text { During growing } \\
\text { season }\end{array}$ & $40 \mu \mathrm{g} / \mathrm{m}^{3}$ & $60 \mu \mathrm{g} / \mathrm{m}^{3}$ & \\
\hline & 8-h exposure & $500 \mu \mathrm{g} / \mathrm{m}^{3}$ & $1100 \mu \mathrm{g} / \mathrm{m}^{3}$ & \\
\hline \multirow[t]{3}{*}{$\begin{array}{l}\text { Acid } \\
\text { precipitation }\end{array}$} & $\begin{array}{l}\text { Annual mean, most } \\
\text { ecosystems }\end{array}$ & $5 \mathrm{~kg} / \mathrm{ha}$ & $40 \mathrm{~kg} / \mathrm{ha}$ & \multirow{3}{*}{$\begin{array}{c}\text { Sensitive organisms in smaller } \\
\text { streams with already low pH } \\
\text { will be eradicated (based on } \\
\text { Bertills and Lövblad 2002) }\end{array}$} \\
\hline & $\begin{array}{l}\text { Annual mean, } \\
\text { sensitive areas }\end{array}$ & $3 \mathrm{~kg} / \mathrm{ha}$ & & \\
\hline & $\begin{array}{l}\text { Annual mean, } \\
\text { forests }\end{array}$ & $8 \mathrm{~kg} / \mathrm{ha}$ & & \\
\hline
\end{tabular}

growth cycle, nutritional status and degree of other air pollutants (Nelson and Sewake 2008; Lebon 2009; Lihnell 1965). Due to this variation, it is difficult to predict in detail how agriculture will be affected by the sulphur fog depicted in our scenario. However, we suppose that even if the mean concentration of $60 \mu \mathrm{g} / \mathrm{m}^{3} \mathrm{SO}_{2}$ during the summer will stress the environment, it will not have any large impacts on the vegetation nor the agricultural sector. We estimate that the individual local peaks, on the other hand, that may be as high as $1100 \mu \mathrm{g} / \mathrm{m}^{3} \mathrm{SO}_{2}$ during $24 \mathrm{~h}$, as depicted in the town Eskilstuna, cause major damage.

The $\mathrm{PM}_{2.5}$ will not influence plants directly, but may cause environmental damage when it is combined with water, and produce acid precipitation. Acid precipitation will cause acidification of land and water, increase the availability of toxic heavy metals in soils, reduce soil fertility, reduce plant growth and damage foliage and flowers (Nelson and Sewake 2008). The $\mathrm{pH}$ value of freshwater lakes and watercourses will be lowered, affecting the ecosystems negatively (WBG 1998). Many freshwater organisms, such as salmon, shells, mussels and crabs, are sensitive to acidification (Nationalencyclopedin 2016). According to Bertills and Lövblad (2002), the critical load for most ecosystems is $5 \mathrm{~kg}$ sulphur per hectare and year. Lakes in sensitive areas will manage less, $3 \mathrm{~kg} / \mathrm{ha}$ annually, and forests will manage as much as $8 \mathrm{~kg} / \mathrm{ha}$ annually. In the scenario, we calculated the mean sulphur load during the heavy rains at the end of the summer, when both $\mathrm{SO}_{2}$ and $\mathrm{PM}_{2.5}$ were removed by wet scavenging from the atmosphere, as $4 \mathrm{~kg} / \mathrm{ha}$ in mean, in the area of eastern Svealand, and as high as $40 \mathrm{~kg} / \mathrm{ha}$ in some smaller areas. We estimated that the consequences of the acid precipitation in the scenario are rather short term, that major rivers will not be affected considerably, but that sensitive organisms in smaller streams that naturally have a low $\mathrm{pH}$ could be eradicated, and that reproduction and growth of less sensitive species are also affected.

The overall impacts on the environment were assessed as being severe, but transient. In the short term, many plants are assumed to be affected by the sulphur dioxide and die, especially in areas where the concentration of the fog is at its highest. Trees and perennial plants are not assumed to be affected to the same degree, but their growth is assumed to be reduced. We estimated that a large part of the harvest in the worst affected areas is destroyed, giving rise to severe economic consequences for the agricultural sector. The feeding of livestock is also assumed to be problematic since large amounts of forage will have been damaged and it would be difficult to import fodder in the right quantities at the right time. Food shortage, on the other hand, is easier to cover via imports, since there is 
broader supply. Finally, the acidification of water courses that already had a low $\mathrm{pH}$ endangered several kinds of organisms, such as crayfish and some fish species.

\subsection{Impacts on electronic equipment}

It is well known that electronic equipment components made of copper, nickel, tin and silver in may corrode when exposed to volcanic gases such as $\mathrm{H}_{2} \mathrm{~S}, \mathrm{SO}_{2}, \mathrm{HCl}$ and $\mathrm{HF}$. The higher the humidity, the faster corrosion occurs (Wilson et al. 2012; World Bank 2007). Observations from 1783, of acidic damage to copper surfaces (Stothers 1996) and whitening of brass pillars on doors (Thordarson and Self 2003), support the assumption that electronics in our Laki-like scenario may be negatively affected. Several studies (see, for example, Watanabe et al. 2006; Hawthorn et al. 2007; Durand and Scott 2005) also show that copper and aluminium corrode more rapidly in a volcanic environment, negatively affecting, for example, computers, telephones and other telecommunications equipment by increasing their failure rates. Those studies, however, were conducted with much higher concentrations of $\mathrm{SO}_{2}$ than depicted in our scenario, and some of them were done in combination with other gases (e.g. $\mathrm{H}_{2} \mathrm{~S}$ ).

Air pollution in many cities implies high-level concentrations of particulate matter and $\mathrm{SO}_{2}$. According to Nielson and $\mathrm{Ho}$ (2007), the concentration of $\mathrm{SO}_{2}$ in Chinese cities on average exceeded $80 \mu \mathrm{g} / \mathrm{m}^{3}$, between 1990 and 1996, which is above the mean value depicted in our scenario. During this period, severe consequences for human health, crops, forests and to some extent buildings and metal structures were reported, but very few observations of electronic failures were made. Not even during the great smog in Beijing, in January 2013, when air pollution reached top levels, were incidents involving electronics reported (Djurberg 2013), which would have been the case if modern electronics are indeed sensitive to high concentrations of sulphur dioxide. An exception is a notice from Intel, about reduced reliability of their systems due to corrosion on printed circuit boards where processors are mounted. This has been particularly noted in China and India, where air pollution is high. ${ }^{11}$

Taken together, there is insufficient evidence for expecting any large consequences for electronic equipment in the scenario, especially as the humidity will be rather low during the period of high pressure.

\section{Societal impacts}

The scenario (Fig. 4) and the narrative (of which a summary is given in annex) were presented in a workshop with representatives from national authorities with an appointed responsibility during societal crises. In the workshop, the scenario was discussed for three time periods: (1) the preparation phase, i.e. the time between the eruption and the arrival of the fog in Sweden, (2) the acute phase, between June 2 and August 23, with increased concentrations of pollutants, and (3) in the long term, i.e. 1-3 years after the fog has disappeared. For all periods, the authorities' representatives were asked, one at a time, to answer the questions: What happens? How is your authority acting? What challenges do you see? What need do you have of support from other authorities? When do you reach a critical level? Do you see any societal consequences? After everyone had provided their

$11 \mathrm{http} / /$ goparallel.sourceforge.net/intel-aims-protect-electronics-air-pollution-damage/, accessed 2014-0717. 
view of the situation, there was a discussion of what Sweden's societal response to the outlined events might be.

The workshop generated comprehensive material, pointing out the Swedish crises management system's weaknesses and strengths in handling a situation like the one depicted in the scenario. The workshop also produced new insights and ideas for how the crises management system, and the communication and collaboration between authorities, could be improved. Those workshop discussions are not further elaborated in this report, but we instead focus on three major societal challenges identified during the workshop. The first challenge is to be able to compile and disseminate relevant information fast enough. This is in order to handle the public's perceived anxiety. Since different authorities have different responsibilities, it was supposed that it is of high importance to coordinate the communication from the authorities, so that information from different sources is coherent.

The second challenge identified is the ability to perform continuous measurements of the contents and concentrations of sulphur dioxide and $\mathrm{PM}_{2.5}$ in the affected areas. This would most likely require mobile detection stations, which are scarce resources today. Reliable measurements of concentrations were perceived to be crucial, both for warning systems and as input to dispersion models used for forecasting. The results, both from the measurements and from the modelling, would then have to be translated into adequate risk assessment and as advice to authorities, healthcare units and the general public. This would be an additional challenge, since even when data are available, expert assessments may provide inconsistent answers to the question of what impacts the haze may result in. It was therefore perceived as being important both to understand the uncertainties and how to communicate them.

A third challenge identified is to be able to meet the large demand for medical care. Based on the scenarios, more than $50 \%$ of the population in the most polluted areas would feel respiratory and eye discomfort. A significant proportion of the affected individuals would try to contact healthcare services for information and many would be expected to seek help in the local healthcare centres. Relevant and timely information would likely reduce the pressure on the healthcare system. For the healthcare and social authorities, this would require well-elaborated public risk communication procedures and the preparedness of the emergency healthcare units for handling a large number of worried individuals.

\section{Discussion}

\subsection{National risk analyses within EU}

Performing national risk analyses is part of the security strategy of the EU, which among other measures sets a framework on how the commission and the member states should work in order to prevent crises. The framework and the work on national analyses are thought to lead to a common understanding of risks and threats within the EU (COM 2009). In Sweden, MSB is responsible for making the analyses and reporting to the Government, and the work presented in this article has been a part of these analyses. There is, however, no established approach within the EU for how this kind of national risk analysis should be done. The scenario-based approach presented in this article has been used in Sweden for several years. The approach includes the development of scenarios that describe identified risks followed by discussions about societal impacts in workshops with experts and representatives from authorities. Our experience is that this way of working is 
appreciated by the participants, since they have a specific situation (the scenario) to discuss. They are forced to consider the responsibilities of their own authority and at the same time they learn about how other authorities respond to the challenge. Together, the participants discuss the many aspects of the challenges they are supposed as needing to meet, what measures they can take to mitigate the negative consequences and when they benefit from collaboration. Assessing the value of this kind of analysis in the context of the broader security work within the EU is to be assessed by MSB and hence lies outside the scope of this article.

\subsection{Different approaches to scenario development}

There are several different approaches for developing a scenario of a volcanic eruption that resembles a historical event. In our case, one possibility was to study the impacts on the society of 1783-1784 and to extrapolate from those with regard to the size of the present population. However, since the society has changed since 1783-1784, regarding, e.g. demography, human health, agriculture and technology development, we did not expect the same impacts as those in 1783-1784. For that reason, we wanted to estimate the concentration of different gases and particles that could be transported to Sweden at ground level and, based on that, make an estimate of the impacts.

To estimate plausible ground-level concentrations of hazards released from the volcano, there are (at least) two possible approaches. Firstly, they could be estimated indirectly from documents describing observations of historical eruptions regarding e.g. vegetation damage, health impacts, visibility reductions and odours. Secondly, ground-level concentrations can be estimated by using atmospheric dispersion models that take transport in the atmosphere and chemical reactivity of the released substances into account. In our study, we tried to combine these two approaches, but with the focus on utilizing results from dispersion models.

As already mentioned, there exist several contemporary records from 1783-1784 from European countries, but it is difficult to make reliable estimations of the concentrations of different substances from the observations described in those records. Sulphur dioxide could for example coexist with other (harmless) sulphur compounds, some of them, such as hydrogen sulphide, having a strong odour at low concentrations, while others are almost odourless. Without knowing the exact composition of the haze, the sensation of a sulphur odour says little about the concentrations and composition of pollutants. Another weakness of historical records is that they say very little about the variation of the concentrations as a function of time.

The approach that uses dispersion models to estimate the concentration fields of the substances that were actually emitted during the Laki eruption also has its drawbacks. Firstly, dispersion models need inputs, such as the mass loading from the volcano, the emission heights of each substance, the dates of the eruption episodes and the meteorological conditions during the 8 months of eruption. Although scientifically based estimations of these data do exist (see, for example, Thordarson and Self 2003), they contain several uncertainties. Secondly, as is inherent in all modelling, the models describing the meteorology, atmospheric chemistry and atmospheric transport of gases need to be accurate in order to yield reliable answers to the questions: Which substances are transported to the surface in mainland Europe, in which concentrations, and when do they occur? 


\subsection{Uncertainties in scenario description and assessment}

The development of the scenario presented in this study, of a sulphur-rich haze originating from an Icelandic volcanic eruption, has been more complex than for the average scenario developed within the Swedish risk assessments. It has required expertise in different fields, such as meteorology, atmospheric chemistry, dispersion modelling and disaster medicine. This also means that there is a wide range of uncertainties in the scenario due to factors such as the source strength of the volcanic eruption, the chemical composition of released gases and particles, the duration of the eruption, the meteorological situation that enables transport to Europe, the variation in concentrations at surface level and the atmospheric chemical processes that oxidize sulphur dioxide to sulphuric acid. Minor changes in these parameters may lead to large variations in the scenario outcome. However, in this study the aim has not been to describe the concentrations of volcanic pollutants from a Laki-like eruption as accurately as possible, but to describe a situation that is relevant, plausible and societally challenging for Sweden.

Besides the uncertainties involved in the scenario development, there are uncertainties in the estimations of the impacts of different pollutants on human health and the environment. These are in some respects more important to resolve, since in a real crisis it will be important to understand the consequences of measured, and forecasted, concentrations of pollutants so that authorities can react correctly and give relevant advice to the public.

When it comes to the effect of the particles on human health, it is evident that long-term exposure to combustion-derived particles in ambient air is associated with decreased quality of life and higher mortality. It is reasonable to assume that volcanic ash particles have similar effects, but they likely differ in degree of toxicity from particles of anthropogenic origin. Clear-cut scientific data describing such differences are, however, lacking (IVHHN 2013). Apart from particle-induced effects, the impacts on human health of high concentrations of sulphur dioxide are far from clear. Most studies of high-dose $\mathrm{SO}_{2}$ exposure have been performed in rodents with uncertainties in relevance for exposures in humans. In this study, we used the Acute Exposure Guideline Levels (AEGL) and the US Environmental Protection Agency Air Quality Index for the estimations of health impacts of $\mathrm{SO}_{2}$. Those guidelines, however, are uncertain in the scenario of 24-h exposure to peak levels. When it comes to $\mathrm{SO}_{2}$, we conclude that it is the high concentration peaks in the scenario that contribute to the negative health consequences and not the long duration time at lower levels. This is in contrast to solid $\mathrm{PM}_{2.5}$, which causes most harm at moderate concentrations in large areas over a longer time, rather than the short peaks of high concentrations in smaller areas (see Sect. 3.1).

The impacts on the environment of the described concentrations also contain uncertainties. There have been several studies of how sulphur dioxide affects vegetation, but the impacts vary between different plants and are dependent on where the plants are in the growth cycle. There have been few studies of plants that grow in Sweden. We know that the vegetation was badly affected during the Laki eruption, but today's crops differ from those cultivated in 1783, making the comparison to the historical observation uncertain. Nevertheless, we have reason to believe that it is the local concentration peaks of $\mathrm{SO}_{2}$ that cause the largest damage to the vegetation, rather than the longer periods of lower concentrations, even if it is also supposed that these are a stress on the environment. The impacts of the acid precipitation at the end of the scenario were found to be small in lakes and larger streams. However, in smaller streams having naturally low $\mathrm{pH}$, it was supposed that sensitive species were affected. 


\subsection{Sensitivity analysis}

The scenario that was developed only describes one of several possible outcomes for a future sulphur fog. This means that the developed scenario can be used as a tool for a structured discussion, but not for dimensioning the crisis management system. We therefore reasoned about what would happen if we changed our preconditions regarding the source terms and the meteorological situation. Firstly, a future volcanic eruption on Iceland could release either less or larger quantities of pollutants than the Laki eruption did. The proportions between different gases could differ from the proportions occurring in 1783-1784 and there may be other kinds of gases released. If the volcanic plume, for example, were to contain considerably larger amounts of hydrogen fluoride (HF) than what was released by the Laki eruption, the concentrations reaching Sweden may be harmful, since the gas is highly toxic to humans, animals and plants. In the scenario, we estimated that a large part of the sulphur dioxide is transported undisturbed to Sweden. If a larger quantity of $\mathrm{SO}_{2}$ were to be converted to sulphuric acid, the impacts on human health would differ from what is assumed in this paper.

Regarding the meteorological situation, any changes in movement of the high-pressure centre's position or the shape, form and gradient of the associated isobar pattern would change concentration levels and the areas that would be affected. In the scenario, eastern Svealand is the most affected region. If, for example, the sulphur fog had occurred in the northern part of Sweden instead, fewer inhabitants would have been exposed to the fog. The acid rain at the end of the scenario did not have any large consequences in the studied area, since the soil is rather lime-rich, causing high $\mathrm{pH}$ in lakes and watercourses and a high buffer capacity. If the sulphur fog had affected other parts of Sweden, for example the south-west or northern parts of the country, where the soil has a much lower $\mathrm{pH}$ and less buffer capacity, small organisms and fish in lakes and watercourses would have been much more affected and the natural recovery of the water ecosystem slower.

The length of the blocking situation also influences the societal consequences. In a real case, it would probably be shorter than in the scenario. However, as is seen above, the major negative impacts of $\mathrm{SO}_{2}$ on human health and environment come from the high concentration peaks, rather than from longer periods of moderate concentrations; high concentration peaks may occur also during shorter blocking situations. The impacts of $\mathrm{PM}_{2.5}$ on human health, on the other hand, are more likely to be proportional to the blocking length as well as to the number of people living in the affected areas.

Moreover, the time of the year for the onset of the eruption would influence the effects of the fog. If the eruption had occurred mainly during the winter, the consequences would likely have been less severe, since the lack of pollen and grass make some allergic individuals less sensitive to air pollution, and the environmental impacts of some plants would be lower. In winter, the incoming radiation from the sun is very low compared to the summer and, as a result, high-pressure systems are often filled with low clouds (water), which would interact with the gases. Another factor that could result in worse consequences than found in our analysis is enhanced oxidation of the sulphur fog by reactions with air pollution at ground level, for example, ozone.

\subsection{Conclusions and future work}

As has been shown in this paper, there is no straightforward way to estimate the plausible ground-level concentrations of hazards from a Laki-like eruption and its consequences on 
the Swedish society. This paper, however, describes the development and analyses of a plausible volcano eruption and its effects on the Swedish society. In the scenario, it was supposed that mainly the high concentrations of $\mathrm{SO}_{2}$ and $\mathrm{H}_{2} \mathrm{SO}_{4}$ would give rise to severe damage on plants, harvests and forage, while a high peak concentration of $\mathrm{SO}_{2}$ and to some extent also long-term precipitation of volcanic ash particles would be the source of a major risk of human health impact. In the workshop with representatives from national authorities, three challenges were identified. The first challenge was to compile and disseminate relevant information fast enough, the second was to be able to perform continuous measurements of hazardous substances in affected areas and the third was to meet the supposed large demand for medical care.

National risk analyses, as described in this paper, require large resources and engage several experts and stakeholders. It would therefore be desirable to further discuss advantages and disadvantages of different approaches for such analyses. In the specific case of assessing the impacts of a volcanic eruption on the Swedish society, more knowledge is needed in several areas, as discussed below.

This study also shows the need for a flexible mobile network of observation stations with the capacity to give accurate concentration levels in near real time. There are many unanswered questions in this field regarding best techniques, methods and responsibilities. Should this type of system be a local, regional or national resource, and to what extent can existing networks be mobilized? There might be useful experiences from other from other hazard monitoring systems, such as the existing CBRN detection systems, ${ }^{12}$ which is used by the civilian rescue services and military defence forces.

Further studies on size, shape and chemical composition of ash particles released from volcanos are needed in combination with studies on their effects on human health.

The finding (Persson et al. 2016) that the trajectories responsible for the highest ground concentrations originate from advection on (much) lower levels than anticipated somewhat contradicts the standard view used in our scenario and by others. ${ }^{13}$ The transport patterns are currently being studied by SMHI and FOI, and will be published in full detail elsewhere (Jakobsson et al. 2016; Thomas et al. 2016).

More work is needed on how horizontal advection interacts with subsidence inversions (in anticyclones) and especially how the transport of gases and particles varies with the diurnal cycle within the planetary boundary layer. We need better understanding of those key factors in order to fully understand how high concentrations can persist on low (ground) levels. This can be done with high-resolution dispersion models driven by numerical weather prediction models. One way to decrease the uncertainties would be to include detailed modelling of the atmospheric chemistry, local topography and differences in air-ground interaction depending on surface properties.

Acknowledgements The work presented in this paper has been done as part of the Swedish national risk and capability analysis, financed by the Swedish Civil Contingencies Agency (MSB). The work was accomplished during 2013 and 2014 and reported to MSB in October 2014. The analysis of the volcanic eruption is part of the broader analysis of Sweden's societal risks and capabilities, about which MSB reported to the Government in March 2015. We would like to thank all the experts, scientists and representatives from Swedish authorities who participated in discussions, meetings and workshops during this study.

12 CBRN-Chemical, Biological, Radiological, and Nuclear.

13 Slow subsidence from high levels in the anticyclone. 
Open Access This article is distributed under the terms of the Creative Commons Attribution 4.0 International License (http://creativecommons.org/licenses/by/4.0/), which permits unrestricted use, distribution, and reproduction in any medium, provided you give appropriate credit to the original author(s) and the source, provide a link to the Creative Commons license, and indicate if changes were made.

\section{Appendix}

Scenario narrative

The Icelandic Meteorological Office, IMO, registers a number of earthquakes in March, in the vicinity of Katla, a volcano that through the years has had some of the most powerful eruptions on Iceland. On May 23, the fissure volcano Eldgjà, in the same volcano system as Katla, starts to erupt. Magma and gases spill out along the fissure, which measures $75 \mathrm{~km}$. The emission of gases at ground level is registered by Icelandic agencies and the plume is measured by satellites and sensors on airplanes.

The Swedish Meteorological Institute (SMHI) runs simulation models using data from the IMO and sends out a warning on May 28 that sulphur could possibly reach ground level in Sweden. At the same time, the weather stabilizes when an area of high pressure situated over east and central Europe starts moving north. On the following day, the first visual signs of the sulphur fog are noticed, even though it is still high in the atmosphere. The sky has taken on a yellowish tone and the sun has turned red.

Ten days after the eruption, on June 2, the sulphur fog reaches the ground in Sweden. Initially, the concentrations of sulphur dioxide and particles are small, and the only effect that is noticed is the reduced visibility. By now, the news media are dominated by reports about the sulphur fog. The flight ban that was introduced when the eruption started, due to volcanic ash over Europe, is cancelled, except for the northern parts of Scandinavia.

Two weeks later, on June 14, high concentrations of sulphate particles are detected. In Eskilstuna, a medium-sized town of 100,000 inhabitants in the middle of the affected area, the concentrations of $\mathrm{PM}_{2.5}$ reach $600 \mu \mathrm{g} / \mathrm{m}^{3}$. The measured $\mathrm{SO}_{2}$ concentration also attains a record $1100 \mu \mathrm{g} / \mathrm{m}^{3}$. The high concentrations only last for $24 \mathrm{~h}$, but during this time the pressure on the health service is extremely high. Concentrations that are almost as high are reported from other places during late June. In an op-ed article, several influential persons demand that the authorities take responsibility for continuous measurements of the pollutants and for installing an early warning system.

Many persons experience headaches and eye, nose and throat irritation. People with pollen allergies are already exposed to allergens at this time of year, and they are further troubled by the sulphur fog. Persons with asthma and other lung diseases experience extra difficulty breathing and especially small children and the elderly need to seek medical care for their problems. The number of persons on sick leave from work increases, as does the number of parents who stay at home in order to take care of sick children. Even animals, principally horses and other grazing animals, are in bad condition due to the sulphur fog.

By the time of Midsummer festivities, in late June, more than a month after the eruption started, the sulphur fog has been stabilized over southern Sweden for 3 weeks. In some places, the vegetation looks as if it has been burnt and sensitive plants wither and die. Farmers become worried about their harvests, and the agricultural sector is predicting huge economic losses. Many forest owners are worried that the forests, mainly those with coniferous trees, are damaged by the sulphurous gas and that their insurance does not apply to this event. Families that have the possibility of travelling north take their chances and leave in order to escape the fog. 
On June 28, the high-pressure area moves eastwards, to Finland, and people in Sweden are relieved. The weather continues to be warmer than normal and dry. The agricultural sector, which has been affected by the sulphur fog, predicts that the decreased production will have to be complemented by greater food imports during the rest of the year and the year after. Since northern Europe is also partly affected by the fog, Sweden has to import food from other parts of Europe and from other continents, at the same time as demand has also risen in all the other affected areas.

After a 2-week break, on July 14 the meteorological situation changes once more and the high-pressure area moves back to Sweden, where it stays until August 10, when it is aborted by a heavy rain. The rain washes out the sulphur and particles from the air and affects the environment negatively. But it also has the advantage of washing out sulphur compounds that have stuck to all kinds of outdoor surfaces. The sulphur compounds are washed to the ground by the water and flushed into ditches, streams and rivers, having an acidic effect on the water. In some places, there is an acid shock, which temporarily lowers the $\mathrm{pH}$ and threatens biological organisms. Lakes that already have a naturally low $\mathrm{pH}$ are those most affected.

On August 23, 3 months after the first eruption in Eldgjà, the weather in Sweden stabilizes and normalises. The temperature is pleasant, and the air is fresh and easy to breathe, but the brown vegetation tells us that the summer that has passed has not been like ordinary summers.

\section{References}

AEGL (2010) Acute exposure guideline levels for selected airborne chemicals, vol 8. National Research Council, Washington. ISBN 0-309-14516-3

AirNow (2016) www.airnow.gov. Accessed 01 May 2016

Ayris PM, Delmelle P, Cimarelli C, Maters EC, Suzuki YJ, Dingwell DB (2014) HCl uptake by volcanic ash in the high temperature eruption plume: mechanistic insights. Geochim Cosmochim Acta 144:188-201

Bertills U, Lövblad G (2002) Kritisk belastning för svavel och kväve. Report 5174, Naturvårdsverkets förlag. ISBN 91-620-5174-1

Brauer M et al (2016) Ambient air pollution exposure estimation for the global burden of disease 2013 . Environ Sci Technol 50:79-88

Camuffo D, Enzi S (1995) Impact of the clouds of volcanic aerosols in Italy. Nat Hazards 11:135-161

Chenet A-L, Fluteau F, Courtillot V (2005) Modelling massive sulphate aerosol pollution, following the large 1783 Laki basaltic eruption. Earth Planet Sci Lett 236:721-731

City of Stockholm (2016) www.miljobarometern.stockholm.se. Accessed 01 May 2016

CPR 16E (1992). Methods for the determination of possible damage to people and objects resulting from releases of hazardous materials, 1st ed. TNO, Netherlands. ISBN 90-5307-052-4

Diao Y, Jianping L, Dehai L (2006) A new blocking index and its application: blocking action in the northern hemisphere. J Clim 19:4819-4839

Direktoratet for samfunnssikkerhet og beredskap (2014) Nasjonalt risikobilde

Djurberg B (2013) Hur världens huvudcykelstad blev världens smoghuvudstad: en studie över Pekings luftföroreningar1980-2013. Uppsats vid språk- och litteraturcentrum vid Lunds universitet

Draxier RR, Hess GD (1998) An overview of the HYSPLIT_4 modelling system for trajectories, dispersion and deposition. Aust Meteorol Mag 47:295-308

Durand M, Scott JS (2005) Geothermal ground gas emissions and indoor air pollution in Rotorua, New Zealand. Sci Total Environ 345:69-80

Finlayson-Pitts BJ, Pitts JN (2000) Chemisty of the upper and lower atmosphere. Academic Press, San Diego

Grahn H, von Schoenberg P, Brännström N (2015) What's that smell? Hydrogen sulphide transport from Bardarbunga to Scandinavia. J Volcanol Geotherm Res 303:187-192

Grattan JP, Pyatt FB (1999) Volcanic eruptions dry fogs and the European palaeoenvironmental record: localised phenomena or hemispheric impacts? Glob Planet Change 2:173-179 
Grattan J, Durand M, Taylor S (2003) Illnes and elevated human mortality in Europe coincident with the Laki Fissure eruption. Geol Soc Spec Publ 213:401-414

Grattan J, Rabartin R, Self S, Thordarson T (2005) Volcanic air pollution and mortality in France 1783-1784. C R Geosci 337:641-651

Gudmundsson MT, Larsen G, Höskuldsson A, Gylfason AG (2008) Volcanic hazards in Iceland. Jökull 58:251-268

Hawthorn GA, Nullet M, Srinivasan R, Hihara LH (2007) Corrosion testing and atmospheric monitoring in an active volcanic. In: Tri-service conference 2007

Highwood EJ, Stevenson DS (2003) Atmospheric impact of the 1783-1784 Laki Eruption: part II climatic effect of sulphate aerosol. Atmos Chem Phys 3:1177-1189

Hobbs PV (2000) Introduction to atmospheric chemistry. Cambridge University Press, Cambridge

IVHHN (2013) International volcanic health hazard network. www.ivhhn.org. 22 Apr 2013

Jakobsson M, Persson C, Fridell SH, Thomas M, Windmark F, Wester J, Asker C, Brännström N, Grahn H, von Schoenberg P (2016) Beredskapsystem och scenarioanalyser för luftspridning över Sverige vid vulkanutbrott, skogsbränder och biologisk smitta. SMHI report no. 2016/32

Lebon SLG (2009) Volcanic activity and environment: impacts on agriculture and use of geological data to improve recovery processes. Thesis, University of Iceland, Faculty of Earth Science

Lihnell D (1965) Luftföroreningarnas inverkan på växter. Utgiven i Växtskyddsnotiser, årgång 29, nummer $2-3$

Lindqvist J (1999) En stokastisk partikelmodel i ett ickemetriskt koordinatsystem (FOI-R-99-01086-862SE, ISSN 1107-9154) (Swedish)

Loughlin SC, Aspinall WP, Vye-Brown C, Baxter PJ, Braban CF, Hort M, Schmid A, Thordarson T, Witham C (2012) Large magnitude fissure eruptions in iceland: source characterisation. Report, British Geological Survey

Mårtensson T, Hedtjärn Swaling V (2016) Yrväderstisdagen 2.0. Polarfront. J Swed Meteorol Soc 43(160):6-12

Maynard AD, Maynard RL (2002) A derived association between ambient aerosol surface area and excess mortality using historic time series data. Atmos Environ 36(36-37):5561-5567

MSB (Swedish Civil Contingencies Agency) (2010) Avdelningen för samordning och insats, Konsekvensbedömning av vulkanutbrott, MSB 2010-4400

Nationalencyclopedin (2016). www.ne.se. Accessed 01 May 2016

Nelson S, Sewake K (2008) Volcanic emissions injury to plant foliage. Plant Disease, Aug 2008, PD-47

Nielsen CP, Ho SH (2007) Air pollution and health damages in China: an introduction and review. Clearing the air: the health and economic damages of air pollution in China. MIT Press, Cambridge, pp 3-50

COM (2009) 82 final of 23.2.2009; the communication on the internal security strategy addressed the need for an approach that integrated security and other policies

Oman L, Robock A, Stenchikov GL, Thordarson T, Koch D, Shindell DT, Gao T (2006) Modeling the distribution of the volcanic aerosol cloud from the 1783-1784 Laki eruption. J Geophys Res 111:1-15

Oppenheimer C, Francis P, Stix J (1998) Depletion rates of sulfur dioxide in tropospheric volcanic plumes. Geophys Res Lett 25:2671-2674. doi:10.1029/98g101988

Roffey R, Lindberg A, Molin L, Wikman-Svahn P (2015) A plausible worst-case scenario of increasing multidrug resistance as a toll for assessing societal risks and capabilities in Sweden. Health Secur 13(3): $174-183$

Schmidt A, Carslaw KS, Mann GW, Wilson M, Breider TJ, Pickering SJ, Thordarson T (2010) The impact of the 1783-1784 AD Laki eruption on global aerosol formation processes and cloud condensation nuclei. Atmos Chem Phys 10:6025-6041

Schmidt A, Ostro B, Carslaw KS, Wilson M, Thordarson T, Mann G, Simmons AJ (2011) Excess mortality in Europe following a future Laki-style Icelandic eruption. PNAS 108(38):15710-15715

Schmidt A, Thordarson T, Oman LD, Robock A, Self S (2012) Climatic impact of the long-lasting 1783 Laki eruption: inapplicability of mass-independent sulfur isotopic composition measurements. J Geophys Res 117:1-10

Stevenson DS, Johnson CE, Highwood EJ, Gauci V, Collins WJ, Derwent RG (2003) Atmospheric impact of the 1783-1784 Laki eruption: part I chemistry modelling. Atmos Chem Phys 3:487-507

Stothers RB (1996) The great fog of 1783. Clim Change 32(79-89):1996

Tabazadeh A, Turco RP (1993) Stratospheric chlorine injection by volcanic-eruptions-HCI scavenging and implications for ozone. Science 260:1082-1086. doi:10.1126/science.260.5111.1082

Thomas MA, Brännström N, Persson C, Grahn H, von Schoenberg P, Robertsson L (2016) Surface air quality implications of volcanic injection heights (submitted manuscript)

Thordarson T (1995) Volatile release and atmospheric effects of basaltic fissure eruptions. PhD Thesis, University of Hawaii at Manoa, UMI number 9532634 
Thordarson T, Self S (2003) Atmospheric and environmental effects of the 1783-1784 Laki eruption: a review and reassessment. J Geophys Res 108:1-29

Thordarson T, Self S, Óskarsson N, Hulsebosch T (1996) Sulfur, chlorine, and fluorine degassing and atmospheric loading by the 1783-1784 AD Laki (Skaftár Fires) eruption in Iceland. Bull Volc 58:205-225

Thordarsson T, Self S (1993) The Laki (Skaftár Fires) and Grímsvötn eruptions in 1783-1785. Bull Volc 55:233-263

USGS (2013). http://volcanoes.usgs.gov/ash/. 06 May 2013

Watanabe M, Hokazono A, Handa, Ichino T, Kuwaki N (2006) Corrosion of copper and silver plates by volcanic gases. Corros Sci 48:3759-3766

WBG (1998) Sulfur oxides. www.worldbank.org

Wilson G, Wilson T, Cole J, Oze C (2012) Vulnerability of laptop computers to volcanic ash and gas. Nat Hazards 63:711-736

Witham CS, Oppenheimer C (2005) Mortality in England during the 1783-4 Laki Craters eruption. Bull Volc 67:15-26

Witham C, Aspinall W, Braban C, Hall J, Loughlin S, Schmidt A, Vieno M, Bealey B, Hort M, Ilyinskaya E, Kentisbeer J, Roberts E, Rowe E (2015) UK Hazards from a large Icelandic effusive eruption. Effusive eruption modelling project final report. Met Office, Exeter

World Bank (2007) Cost of pollution in China 